\title{
Evaluation of economical and rapid method of plant DNA extraction for PCR analysis of different crops
}

\author{
Sweta Sinha ${ }^{1}$ and Amarendra Kumar ${ }^{2 *}$ \\ ${ }^{1}$ Department of Molecular Biology and Genetic Engineering, Bihar Agricultural University, Sabour, Bhagalpur- \\ 813210 (Bihar), INDIA \\ ${ }^{2}$ Department of Plant Pathology, Bihar Agricultural University, Sabour, Bhagalpur-813210 (Bihar ), INDIA \\ *Corresponding author. E-mail: kumaramar05@gmail.com
}

Received: July 18, 2016; Revised received: February 5, 2017; Accepted: April 26, 2017

\begin{abstract}
In the recent genomic era, polymerase chain reaction (PCR) has become a basic tool in molecular studies and the success of PCR depends upon the template DNA. PCR technique is quite robust and often unnecessary to extract high quality of DNA and hence crude DNA can be used as template for amplification. Therefore, we have evaluated $\mathrm{NaOH}$-Tris DNA extraction method for PCR analysis because this is very simple, time saving and safe without the need to use expensive or rare materials and laboratory apparatus. This method only requires a small amount of leaf tissue, $\mathrm{NaOH}$, Tris, micro tube and plastic pestle. The amplified PCR products showed clear, sharp and uniform bands gave similar results as compared with the modified CTAB method. The DNA obtained is crude contains impurities like protein, RNA but these impurities did not affect PCR amplification. This DNA extraction method is evaluated for brinjal (Solanum melongena L.), chilli (Capsicum annuum L.), rice (Oryza sativa L.) and tomato (Solanum lycopersicum L.) crop. Many other crop plants could also be amplified using the same DNA extraction method for molecular analysis of large samples. Thus, the use of $\mathrm{NaOH}$-Tris method will allow researchers to obtain DNA from plant quickly for use in molecular studies.
\end{abstract}

Keywords: DNA extraction, $\mathrm{NaOH}, \mathrm{PCR}$, Tris

\section{INTRODUCTION}

Polymerase chain reaction has become a basic tool in molecular biology and is employed in a variety of molecular studies including genetic diversity analysis, marker assisted selection, quantitative trait loci QTL mapping, purity analysis and varietal identification. The major limitation for these studies is time and cost for extracting DNA in analyzing large plant samples. The extraction of DNA from plant tissue is time consuming, laborious and involves the use of many expensive chemicals (Dellaporta et al., 1983; Saghai-Maroof et al., 1984; Bernatzky and Tansley, 1986; Lassner et al., 1989; Doyle and Doyle, 1990). The conventional method for extracting DNA from plant tissue are often unnecessary for routine genotyping because it needs multiple steps require special chemicals or instruments and they are not suitable for use with a large number of plant samples. Therefore, the genomic DNA extraction procedure for large scale genotyping analysis must be very simple, inexpensive and they can be used without compromising the accuracy of results. Nevertheless, the issue prompted us to survey previously published literature for rapid extraction protocols. There are various methods of rapid DNA extraction from plant tissues, but almost all of these involve liquid nitrogen for efficient grinding of plant tissues and use of organic solvents (Edwards et al., 1991; Langridge et al., 1991; Berthoumieu and Meyer, 1991; Oard and Dronavalli, 1992; Cheung et al., 1993; Chunwongse et al., 1993; Wang et al., 1993; Guidet, 1994; Thomson and Henry, 1995; Haymes, 1996; Lange et al., 1998). However, $\mathrm{NaOH}-$ Tris extraction method (Wang el al., 1993) was found to be effective for the molecular analysis in terms of success rate, cost, speed and simplicity but still not popular. Therefore, in the present study $\mathrm{NaOH}$ -Tris extraction method has been evaluated for rapid extraction of DNA from four crops namely brinjal (Solanum melongena L.), chilli (Capsicum annuum L.), rice (Oryza sativa L.) and tomato (Solanum lycopersicum L.) to minimize time and the use of laboratory materials.

\section{MATERIALS AND METHODS}

Plant material: In this study, four brinjal varieties (Arka Shirish, Arka Neelkanth, Lalpari, Arka Anand), four chilli varieties (Guntur Hope, Bullet, Pusa Jawala, Pusa Sadabahar), three tomato varieties (Arka Vikash, Arka Meghali, Arka Saurabh) and three rice varieties (Rajendra Sweta, Sabour Shree, Swarna Sub1) were used for DNA extraction.

DNA extraction: Ten milligrams of fresh leaf tissue of each variety were used to extract DNA. The tissues were homogenized with $100 \mu \mathrm{l} 0.5 \mathrm{M} \mathrm{NaOH}$ in $1.5 \mathrm{ml}$ 
sterile centrifuge tubes with a plastic pestle for $1 \mathrm{mi}-$ nute. After homogenization, $900 \mu \mathrm{l}$ of $100 \mathrm{mM}$ Tris $\mathrm{pH} 8.0$ were added and vortexed for 30 seconds and then centrifuged at $10,000 \mathrm{~g}$ for 1 minute at $25^{\circ} \mathrm{C}$ and $1 \mu \mathrm{l}$ of the supernatant was used as the DNA template for PCR analysis. DNA was also extracted by using modified CTAB method which served as control for comparison. The time required for extracting DNA with both methods was recorded and compared using ten randomly selected leaf samples.

PCR amplification: DNA extracted were used for PCR amplifications on a Eppendorf Mastercycler (Eppendorf, USA) in a total volume of $15 \mu \mathrm{l}$ containing $1 \times$ PCR buffer, $0.2 \mathrm{mM}$ dNTPs, $0.2 \mu \mathrm{M}$ each forward and reverse primer (Table 1), 0.5 U Taq DNA Polymerase (Xcelris, India) and $1 \mu$ template DNA using the following profile: a 4 minutes denaturation at $94{ }^{\circ} \mathrm{C}$ and 35 cycles of 30 seconds denaturation at $94^{\circ}$ $\mathrm{C}, 60$ seconds annealing at $55^{\circ} \mathrm{C}$ for SSR/gene specific markers and a 60 seconds extension at $72{ }^{\circ} \mathrm{C}$, followed by a final extension at $72{ }^{\circ} \mathrm{C}$ for 5 minutes. The PCR products were resolved by electrophoresis in 1.5 $\%$ (R2M1S marker) and 2.5\% (CAMS351, emb01M15 and ART5 marker) agarose gels (HiMedia) using $1 \mathrm{X}$ TAE buffer. The amplicons were visualized by UV light and documented (Uvitec gel doc system, UK). PCR Amplifications were carried out for at least twice for each sample. A DNA ladder $100 \mathrm{bp}$ (Xcelris, India) was used as molecular markers to estimate the size of the amplicons.

\section{RESULTS AND DISCUSSION}

Comparison of DNA extraction method: $\mathrm{NaOH}-$ Tris and modified CTAB: DNA extraction is prerequisite and most important step in molecular studies. Consequently, it is essential to use a suitable DNA extraction method which is not only rapid and simple but also use small amount of tissue and extraction solutions. Considering these facts $\mathrm{NaOH}-\mathrm{Tris}$ for extracting crude plant DNA was evaluated in this study. The NaOH-Tris method is much faster than other rapid DNA extraction protocols and the complete DNA extraction procedure takes 2.30 minute. This method, involves fewer steps, required mirocentrifuge tubes, less time and therefore is more economic as cost per sample is reduced when compared to conventional methods. Compared to modified CTAB method, the $\mathrm{NaOH}-$ Tris method has significant advantages. First, the $\mathrm{NaOH}$-Tris method does not involve the mechanical breaking of plant cell walls, incubation at $65^{\circ} \mathrm{C}$ or $37{ }^{\circ} \mathrm{C}$, DNA purification using phenol or chloroform and the time required for DNA extraction is therefore reduced greatly (Table 2). In a single day, one person can complete DNA extraction from more than 200 leaf samples using this method. This method has been routinely used to extract DNA from rice for marker assisted selection in our laboratory. Second, the $\mathrm{NaOH}$-Tris method does not require liquid nitrogen or an ultra low temperature centrifuge, which may be unavailable to many small laboratories and the method only requires a normal centrifuge. This method is suitable for a general molecular biology laboratory and is easily learned by layman. Third, the $\mathrm{NaOH}$-Tris method does not use toxic chemicals (e.g., liquid nitrogen, CTAB, $\beta$ mercaptoethanol, phenol or chloroform) and so it is safe for users and does not require disposal of harmful wastes. Fourth, in this method, very common chemicals were used for DNA extraction instead of costly chemicals. Fifth, the $\mathrm{NaOH}$-Tris method requires only a small quantity of plant tissue $(10 \mathrm{mg})$ and there is no sample waste whereas in modified CTAB method requires large quantities of plant tissue and ground in a mortar and pestle with liquid nitrogen. Finally, contaminant DNA can cause significant problems with PCR (Kwok and Higuchi, 1989), but the NaOH-Tris method reduces the chance of cross contamination

Table 1. List of primers used in the study for PCR amplification.

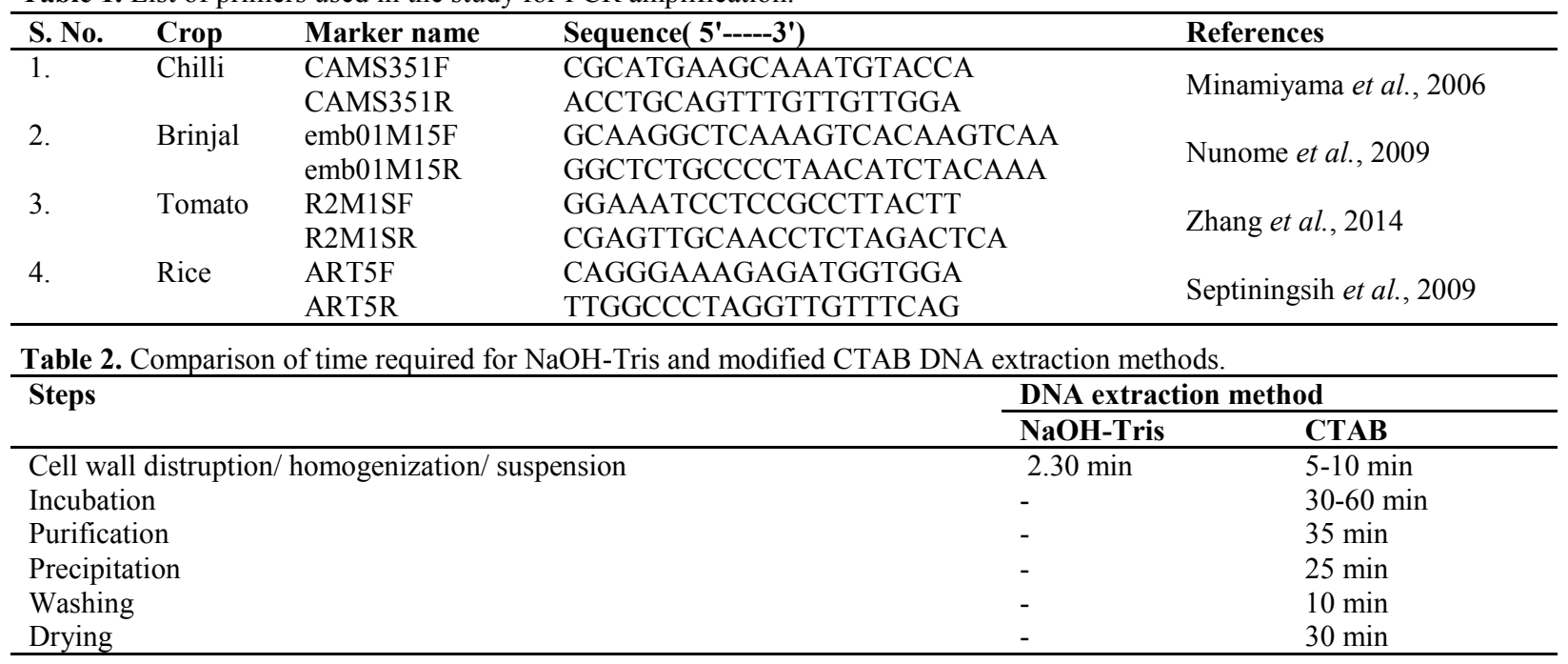

Dash (-) means the lack of a step 
Sweta Sinha and Amarendra Kumar / J. Appl. \& Nat. Sci. 9 (2): 866 - 870 (2017)

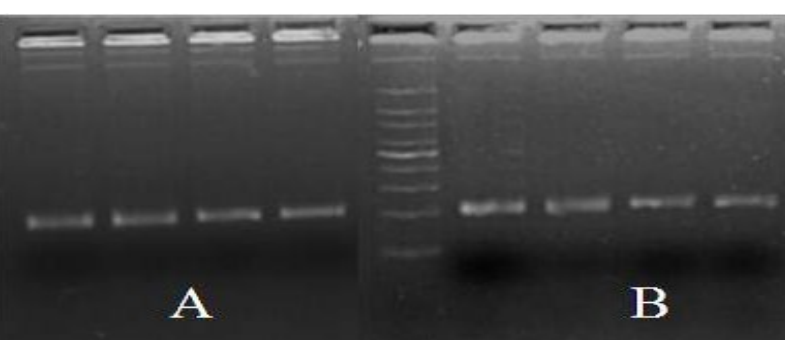

Fig. 1. PCR amplification using CAMS-351 primer in four different chilli genotypes. DNA isolated by A) NaOH-Tris method B) CTAB method. Lane M: 100 by DNA ladder, Lane 1-4: Chilli genotypes Guntur Hope, Bullet, Pusa Jawala, Pusa Sadabahar.

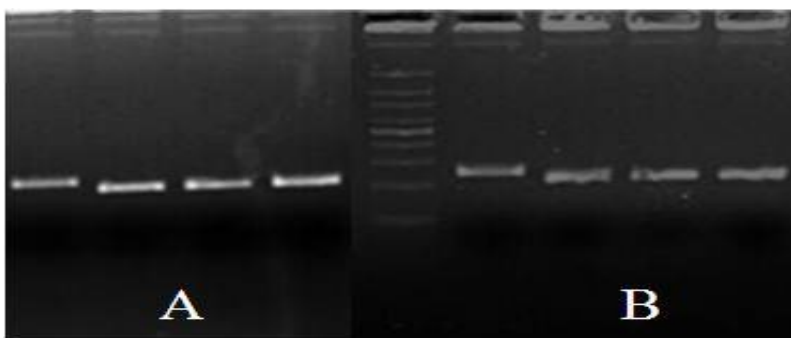

Fig. 2. $P C R$ amplification using emb01M15 primer in four different brinjal genotypes. DNA isolated by A) $\mathrm{NaOH}$-Tris method B) CTAB method. Lane M: 100 by DNA ladder, Lane 1-4: Brinjal genotypes Arka Shirish, Arka Neelkanth, Lalpari , Arka Anand

because it prevent many of the surface contacts (e.g., contact between DNA and mortar, pestle, spatula, multiple pipetting and other equipment) that occur with the modified CTAB method.

Comparison of $\mathrm{NaOH}-\mathrm{Tris}$ and modified CTAB extractions for PCR amplification: A single DNA extraction method cannot always be successfully applied to a broad range of crop plants. With the present $\mathrm{NaOH}-$ Tris method, it was possible to extract DNA from brinjal (Solanum melongena L.), chilli (Capsicum annuum L.), rice (Oryza sativa L.) and tomato (Solanum lycopersicum L.). The crude DNA extracted from these crops was sufficient for SSR and gene specific markers. All the DNA samples produced a clear, sharp and uniform band and at the same time it gave similar results as compared with the modified CTAB

Table 3. Comparison of $\mathrm{NaOH}-$ Tris and modified $\mathrm{CTAB}$ DNA extraction cost.

\begin{tabular}{lcc}
\hline \multirow{2}{*}{ Chemicals/consumables } & \multicolumn{2}{c}{ Cost per sample (Rs) } \\
\cline { 2 - 3 } & NaOH-Tris & CTAB \\
\hline Liquid nitrogen & - & 0.85 \\
Extraction buffer & 0.01 & 0.20 \\
Chloroform:isoamyl alcohol & - & 3.60 \\
Isopropanol & - & 1.25 \\
70\% Ethanol & - & 0.05 \\
1.5 ml micro tube & 0.83 & 0.83 \\
1000 $\mu$ Tips & - & 0.54 \\
200 $\mu 1$ Tips & - & 0.71 \\
Total cost per sample & 0.84 & 8.03 \\
\hline
\end{tabular}

Dash (-) means the chemicals or consumables not required

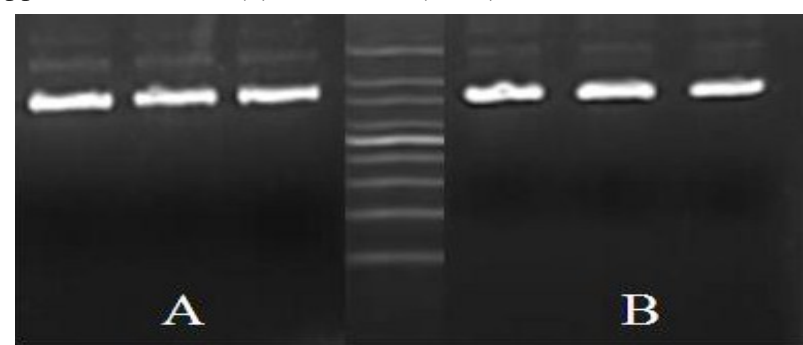

Fig. 3. $P C R$ amplification using $R 2 M 1 S$ primer in three different tomato genotypes. DNA isolated by A) NaOH-Tris method B) CTAB method. Lane M: 100 by DNA ladder, Lane 1-3: Tomato genotypes Arka Vikash, Arka Meghali, Arka Saurabh

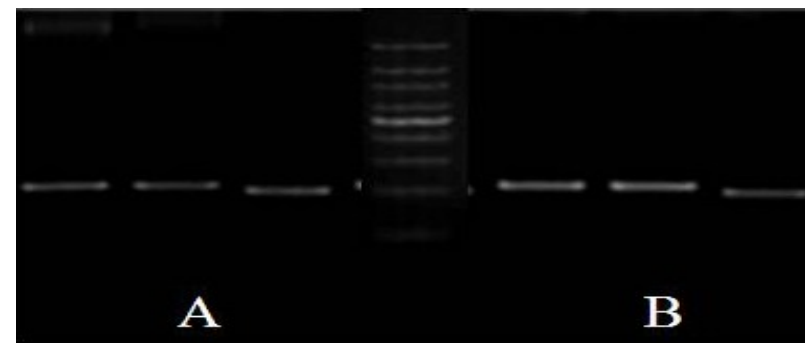

Fig. 4. $P C R$ amplification using ARTS primer in three different rice genotypes. DNA isolated by A) $\mathrm{NaOH}$-Tris method B) CTAB method. Lane M: 100 by DNA ladder, Lane 1-3: Rice genotypes Rajendra Sweta, Sabour Shree, Swarna Subl

method (Fig. 1, 2, 3, 4). The DNA template was suitable for amplification by Taq DNA polymerase. No inhibition of Taq DNA polymerase activity was observed, indicating no disadvantage of use of crude DNA extracted and which can be efficiently used for various types of molecular studies (Collard et al., 2007). The $\mathrm{NaOH}$ solution allows sufficient dilution of the extract and significantly reduces the effect of potential inhibitors of PCR. Zhang et al. (2000) reported $\mathrm{NaOH}$ DNA extraction method did not reliably produce PCR amplification products of $>600 \mathrm{bp}$ in length. However, the DNA extracted in our study was suitable for PCR amplification of products $>600 \mathrm{bp}$ in length (Fig. 1c). Warner et al. (2001) reported a rapid DNA extraction method which requires $\mathrm{NaOH}$ were easily degraded in barley. The DNA samples extracted in the present study were also stable and could be stored for a month without degradation.

Cost estimation: The cost required in the DNA extraction for the $\mathrm{NaOH}$-Tris and modified CTAB method was estimated. A cost for chemicals (HiMedia make) and plastic consumable (Tarsons make) items like pipette tips and $1.5 \mathrm{ml}$ tubes is only included in the cost estimations. The cost involved in the extraction by $\mathrm{NaOH}$-Tris method is Rs. 0.84 per sample as against a cost of Rs. 8.03 involved in DNA extraction through modified CTAB method. Thus NaOH-Tris method is effective for reducing the cost of DNA extraction (cost only for $\mathrm{NaOH}$, Tris and micro tube).

$\mathrm{NaOH}$-Tris method is not only very simple, but is also time and cost effective. Thus, this method will be suit- 
able for marker assisted breeding programs, where we can save considerable time and expense which is important criteria for marker assisted selection as the sample number for each analysis is very high. Many different plants could be amplified using the same DNA extraction method and the same PCR protocol.

\section{Conclusion}

We found that modified CTAB DNA extraction procedures are unnecessarily expensive, laborious and time consuming for routine genotyping of crop plants. The present $\mathrm{NaOH}$-Tris method delivers PCR-ready DNA from different crop plants for use in molecular studies is much cheaper in terms of time, chemical use and labor input. The time required for DNA extraction is 2.30 minutes, whereas modified CTAB method took 3 hour. In a single day, one person can complete DNA extraction from more than 200 leaf samples using $\mathrm{NaOH}-\mathrm{Tris}$ method. The cost involved in the extraction is approximately Rs. 0.80 per sample as against a cost of Rs. 8 involved in DNA extraction through modified CTAB method, thus reducing the cost by 10 times. Moreover, this method requires only few milligrams of leaf, no expensive equipment and chemicals and is suitable for large scale genotyping so making method economic for marker assisted breeding.

\section{ACKNOWLEDGEMENTS}

The authors are highly thankful to Bihar Agricultural University, Sabour for providing laboratory facilities to carry out this work. This research work was financially supported by Improved Rice-based Rainfed Agricultural Systems (IRRAS) project of IRRI, Philippines. The authors also thank Dr Vijay Kumar, Department of Vegetable Science and Floriculture, Bihar Agricultural University, Sabour for providing plant material of vegetables.

\section{REFERENCES}

Bernatzky, R. and Tanksley, S. D. (1986). Method for detection of single or low copy sequences in tomato on southern blots. Plant Molecular Biology Report,4:37-41

Berthoumieu, P. and Meyer, C. (1991). Direct amplification of plant genomic DNA from leaf and root pieces using PCR. Plant Molecular Biology Report, 17: 555-557

Cheung, W. Y., Hubert, N. and Landry, B. S. (1993). A simple and rapid DNA microextraction method for plant, animal, and insect suitable for RAPD and other PCR analyses. PCR Methods and Applications, 3: 69-70

Chunwongse, J., Martin, G. B. and Tanksley, S. D. (1993). Pre-germination genotypic screening using PCR amplification of half-seeds. Theoretical and Applied Genetics, 86: 694-698

Collard, B. C. Y., Das, A., Virk, P. S. and Mackill, D. J. (2007). Evaluation of 'quick and dirty' DNA extraction methods for marker-assisted selection in rice (Oryza sativa $\mathrm{L}$.). Plant Breeding, 126: 47-50

Dellaporta, S. L., Wood, J. and Hicks, J. B. (1983). A plant DNA minipreparation: version II. Plant Molecular Biol- ogy Report, 1: 19-21

Doyle, J. J. and Doyle, J. L. (1990). Isolation of plant DNA from fresh tissue, Focus, 12: 13-15

Edwards, K., Johnstone, C. and Thompson, C. (1991). A simple and rapid method for the preparation of plant genomic DNA for PCR analysis. Nucleic Acids Research, 19(6): 1349

Guidet, F. (1994). A powerful new technique to quickly prepare hundreds of plant extracts for PCR and RAPD analyses. Nucleic Acids Research, 22: 1772-1773

Haymes, K. M. (1996). Mini-prep method suitable for a plant breeding program. Plant Molecular Biology Report, 14: 280-284

Kwok, S. and Higuchi, R. (1989). Avoiding false positives with PCR. Nature, 339: 237-238

Lange, D. A., Penuela, S., Denny, R. L., Mudge, J., Concibo, V. C., Orf, J. H. and Young, N. D. (1998). A plant DNA isolation protocol suitable for polymerase chain reaction based marker-assisted breeding. Crop Science, 38:217220

Langridge, U., Schwall, M. and Langridge, P. (1991). Squashes of plant tissue as substrate for PCR. Nucleic Acids Research, 19: 6954-6956

Lassner, M. W., Peterson, P. and Yoder, J. I. (1989). Simultaneous amplification of multiple DNA fragments by polymerase chain reaction in the analysis of transgenic plants and their progeny. Plant Molecular Biology Reporter, 7: 116-128

Minamiyama, Y., Tsuro, M. and Hirai, M. (2006). An SSRbased linkage map of Capsicum annuum. Molecular Breeding, 18: 157-169

Nunome, T., Negoro, S., Kono, I., Kanamori, H., Miyatake, K., Yamaguchi, H., Ohyama, A. and Fukuoka, H. (2009). Development of SSR markers derived from SSR -enriched genomic library of eggplant (Solanum melongena L.). Theoretical and Applied Genetics, 119: 1143-1153

Oard, J. H. and Dronavalli, S. (1992). Rapid isolation of rice and maize DNA for analysis by random-primer PCR. Plant Molecular Biology Report, 10: 236-241

Saghai-Maroof, M. A., Soliman, K. M., Jorgensen, R. A. and Allard, R. W. (1984). Ribosomal DNA spacer-length polymorphism in barley: Mendelian inheritance, chromosomal location, and population dynamics. Proceedings of the National Academy of Sciences, USA, 81: 8014-8019

Septiningsih, E. M., Pamplona, A. M., Sanchez, D. L., Neeraja, C. N., Vergara, G. V., Heuer, S., Ismail, A. M. and Mackill, D. J. (2009). Development of submergence tolerant rice cultivars: the Sub1 locus and beyond. $\mathrm{An}$ nals of Botany, 103: 151-160

Thomson, D. and Henry, R. (1995). Single-step protocol for preparation of plant tissues for analysis by PCR. Biotechniques, 19: 394-400

Wang, H., Qi, M. and Cutler, A. J. (1993). A simple method of preparing plant samples for PCR. Nucleic Acids Research, 21: 4153-4154.

Warner, P., Karakousis, A., Schiemann, A., Eglinton, J., Langridge, P. and Barr, A. (2001). An investigation of a rapid DNA extraction method for routine MAS in the S.A. Barley Improvement Program. Proceeding of the 10th Australian Barley Tech Symposium

Zhang, J. and Stewart, J. M. (2000). Economical and rapid 
Sweta Sinha and Amarendra Kumar / J. Appl. \& Nat. Sci. 9 (2): 866 - 870 (2017)

method for extracting cotton genomic DNA. The Journal of Cotton Science, 4: 193-201

Zhang, C., Liu, L., Wang, X., Vossen, J., Li, G., Li, T., Zheng, Z., Gao J., Guo, Y., Visser, R. J. F., Li, J., Bai,
Y. and Du, Y. (2014). The $P h-3$ gene from Solanum pimpinellifolium encodes CC-NBS-LRR protein conferring resistance to Phytophthora infestans. Theoretical and Applied Genetics, 127: 1353-1364 